\title{
U.S. Geological Survey Programs in New Mexico
}

\section{U.S. Department of the Interior - U.S. Geological Survey}

The various programs of the U.S. Geological Survey (USGS) reflect a responsiveness to New Mexico's needs for earthscience information. Since USGS topographers first arrived at Fort Wingate, New Mexico, in 1880, the USGS has provided the earth-science information on which many decisions regarding New Mexico's natural resources have been based.

\section{Hydrologic Monitoring}

Because New Mexico has limited water resources, hydrologic data are essential for administering and managing these resources and for monitoring and assessing trends in hydrologic conditions. The USGS has a network of data-collection stations (fig. 1) at selected locations throughout New Mexico that record information on streamflow and stage, reservoir and lake storage, ground-water levels, spring discharge, and the quality of surface and ground waters. These stations, which are funded in cooperation with Federal, State, and local agencies, have been established to provide a long-term data base. The hydrologic datacollection program in New Mexico current-

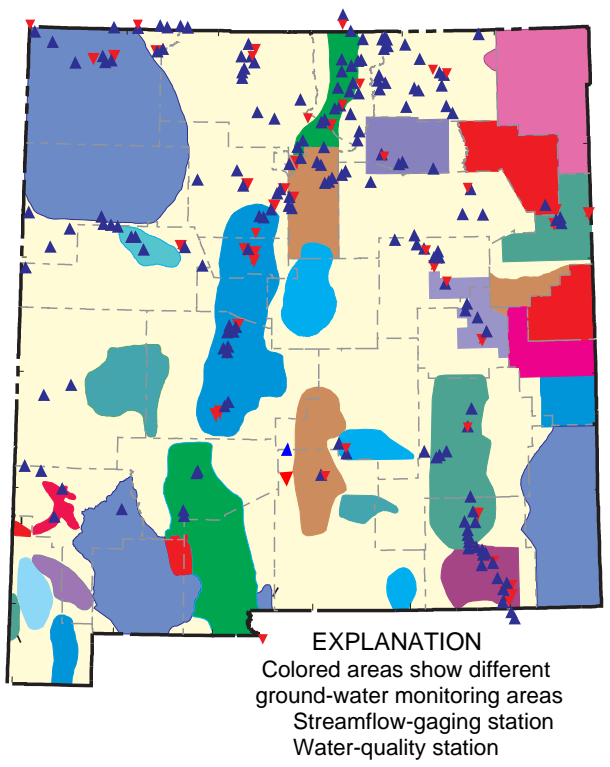

Figure 1. Hydrologic monitoring stations and areas. ly consists of 158 continuous streamflowgaging stations, 173 streamflow partialrecord stations, 46 precipitation stations, 6,100 ground-water wells, and 54 waterquality stations.

\section{Philmont Scout Ranch Maps}

Nearly 20,000 Scouts per year at the Philmont Scout Ranch, Boy Scouts of America, use USGS topographic maps as part of a planning packet to navigate on hikes and pack trips that range from 50 to 100 miles. The Philmont Scout Ranch also finds these maps valuable for formulating fire suppression strategy, search and rescue, and general planning. The Ranch entered into an agreement with the USGS to produce three 1:24,000-scale sectional maps of the ranch and to update the 1:45,000-scale map that covers the entire Ranch. These maps were updated by the USGS in 1995 with an additional 1:24,000-scale map produced that shows newly acquired additions to the Ranch.

\section{Water Quality in Eastern Bernalillo County}

The residents of eastern Bernalillo County are concerned about the current quality of ground water and its vulnerability to contamination. Because the county is undergoing rapid population growth and expanded development, demands on ground water (the only source of drinkingwater supplies) and the potential for ground-water contamination (particularly degradation from sewage effluent) are increasing. Many of the homes in unincorporated areas use septic systems. Concentrations of nitrate in ground water have exceeded the U.S. Environmental Protection Agency's (USEPA) maximum contaminant level of 10 milligrams per liter in some parts of eastern Bernalillo County.

The USGS and the Bernalillo County Environmental Health Department entered

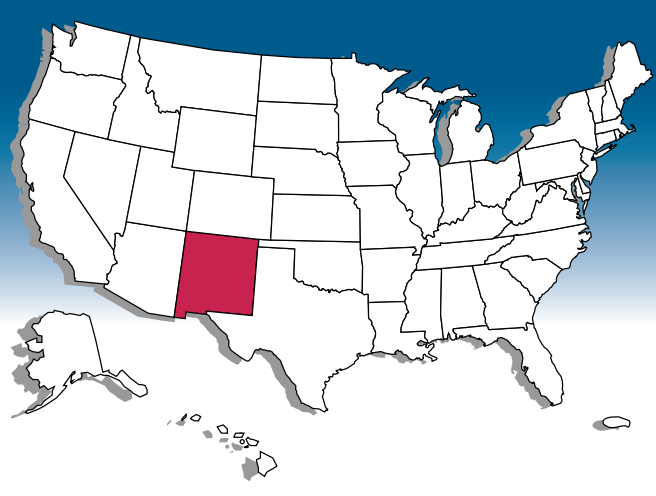

Index of Subjects

Hydrologic Monitoring

Philmont Scout Ranch Maps

Water Quality in Eastern Bernalillo County

Topographic Mapping

U.S./Mexico Border Mapping

Sharing Spatial Data

Middle Rio Grande Basin Studies

Ground-Water Depletion in the Albuquerque Basin

Effects of Ground-Water Withdrawal on Flow in the Rio Grande

Capitan Aquifer and Tansill Formation Data Collection

Water-Quality Study of the Vermejo Irrigation Project

Digital Map Coverage

National Water-Quality Assessment Program

into several cooperative agreements between 1989 and 1995 to collect groundwater data in several unincorporated areas of the county, including the eastern mountain area, the northeastern heights, and the northern and southern valleys of Albuquerque. Water from more than 100 wells in these areas was sampled and analyzed for a variety of chemical constituents; water levels were measured when possible. Many of the wells sampled contained water that exceeded the USEPA's primary drinkingwater standards for nitrates and secondary drinking-water standards for dissolved solids, sulfate, chloride, iron, or manganese. Data collected indicate that concentrations of some constituents have increased significantly over the past 6 years and that, in most areas, the water table is declining. This monitoring effort will help the county determine the current state of ground-water quality and levels and possible changes in the future.

\section{Topographic Mapping}

USGS 1:24,000-scale topographic maps ( 1 inch on the map represents 2,000 feet on the ground) have long been favorites with the general public for outdoor uses, including hiking, camping, exploring, and backcountry fishing expeditions. These maps 
depict basic natural and cultural features of the landscape, such as lakes and streams, highways and railroads, boundaries, and geographic names; contour lines are used to depict the elevation and shape of terrain. New Mexico is covered by 2,035 maps at this scale.

Today, scientists and engineers increasingly depend on digital (computerized) base maps for their research and analysis. The USGS is working to ensure the availability of accurate digital cartographic data for the Nation to facilitate ground-water and hazards studies and resource-management activities.

\section{U.S./Mexico Border Mapping}

Federal, State, and local agencies and other organizations in the United States and Mexico need cartographic data. The USGS, in cooperation with these agencies and other organizations, is developing digital map data for the U.S./Mexico border area (fig. 2). An area on each side of the border was selected for obtaining the cartographic data necessary to meet the mapping needs of the cooperating organizations. A variety of topological and water-resources projects also is underway, some of which extend as much as 250 miles on each side of the border. Color infrared aerial photography is being obtained during 1996 for the U.S. side of the border area. In 1997, the USGS plans to produce digital orthophotoquads (DOQ's; see "Digital Map Coverage" on p. 4) from these photographs. The DOQ's are useful for revising maps and other data sources along the border, including USGS 1:24,000-scale topographic maps. The digital map data support a wide range of studies of the environment and resource management on both sides of the border.

To meet some initial user needs in 1996, the USGS is digitizing Boundary and Public Land Survey System data from USGS $1: 24,000$-scale maps that cover the areas on

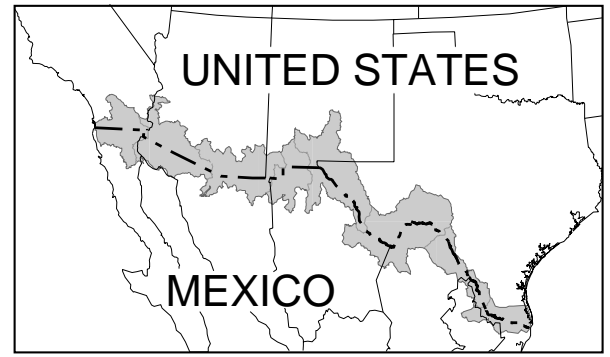

Figure 2. Spatial extent of a shared U.S./Mexico water-resources project. each side of the border. The USGS also is producing 1:24,000-scale digital raster graphics (DRG's) of the 1:24,000-scale maps in the area. DRG's are scanned images of USGS topographic maps that can be used as a base to register, collect, and revise other data themes. Additional information about U.S./Mexico border mapping can be found at the U.S.-Mexico Border Field Coordinating Committee World Wide Web page at:

\section{http://www.doi.gov/fcc/}

\section{Sharing Spatial Data}

The Federal Geographic Data Committee (FGDC) through the USGS established the Competitive Cooperative Agreements Program (CCAP) to help form data-sharing partnerships with the non-Federal sector and to provide funding to State and local government agencies, academia, and the private sector to encourage resource-sharing projects through technology, networking, and interagency coordination. The CCAP funded the development of a National Spatial Data Infrastructure clearinghouse around New Mexico's Resource Geographic Information System (RGIS) Program by the University of New Mexico Earth Data Analysis Center. This project involves modifying the current RGIS Program metadata standard (metadata are used to describe data sets) to make RGIS Program and State agency data more compatible with FGDC metadata standards.

\section{Middle Rio Grande Basin Studies}

About one-half of the total population of New Mexico depends on the ground-water resources of the middle Rio Grande Basin. The population in this area is increasing rapidly, and urban planners in the municipalities and pueblos in the Santa Fe/Albuquerque urban corridor need geologic information. A complete characterization of these resources is hampered by a scarcity of data in the northern and southern areas of the Basin. In response, the USGS has created a program to provide additional data. Ongoing studies emphasize refinement of estimates of the processes and quantities of water moving through the ground-water system. The USGS is collecting and compiling data for 1:100,000-scale geologic maps, conducting areal geophysical surveys, and compiling maps of faults and related structures in the Basin.
In 1995, the USGS National Cooperative Geologic Mapping Program (NCGMP) began a new project, which is called STATEMAP, that provides funding for important geologic mapping in New Mexico for the Los Alamos, the Albuquerque, and the Belen 30- by 60-minute quadrangles (fig. 3), which cover the area of the Santa Fe/Albuquerque urban corridor. The maps, which are prepared in cooperation with the New Mexico Bureau of Mines and Mineral Resources, the University of New Mexico, New Mexico Tech, and the Los Alamos National Laboratory, are being produced as multipurpose digital geographic information system data bases and conventional paper products to provide baseline geologic data.

\section{Ground-Water Depletion in the Albuquerque Basin}

The USGS, in cooperation with the city of Albuquerque, conducted a study during 1993-94 that helped confirm that the most productive zone of the Santa Fe Group aquifer system is much less extensive and

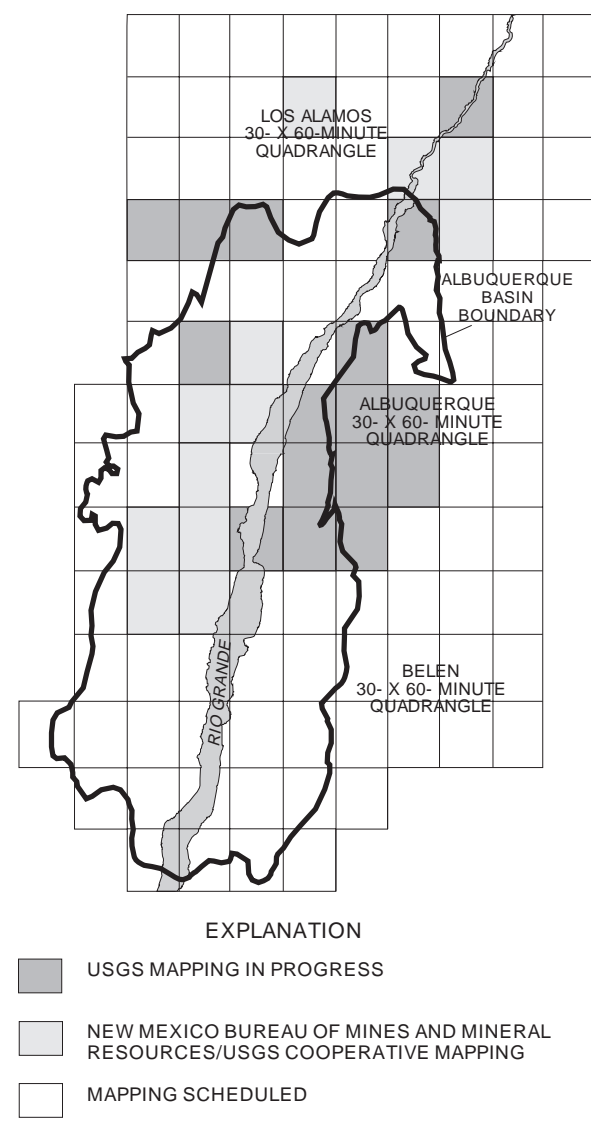

Figure 3. Status of geologic mapping of the middle Rio Grande Basin. 
thinner than was previously assumed. Water-level declines are greater than predicted by hydrologic investigations in the 1960's, and nonpumping water levels in some city production wells have declined more than 100 feet in recent years.

The ground-water flow model developed during the 1993-94 study was revised in 1995 (fig. 4) to include new information on the hydrogeologic framework of the Albuquerque Basin. Although the differences between the two versions of the model are significant, output from the revised model does not contradict previous conclusions about the effects of city ground-water withdrawals on flow in the Rio Grande or on the net benefits of an effort to conserve ground water.

\section{Effects of Ground-Water Withdrawal on Flow in the Rio Grande}

The USGS and the City of Albuquerque are studying hydrologic relations between the Santa Fe Group aquifer system and the Rio Grande so that the effects of groundwater withdrawal from the aquifer on flow in the Rio Grande can be defined better. A 1995 USGS study indicated that the aquifer is not being recharged by the river to the extent once thought. Ground water is the only water supply for Albuquerque, which is the largest municipality in New Mexico.

To help determine the hydraulic connection between the aquifer and the river, a large-scale aquifer test was conducted at

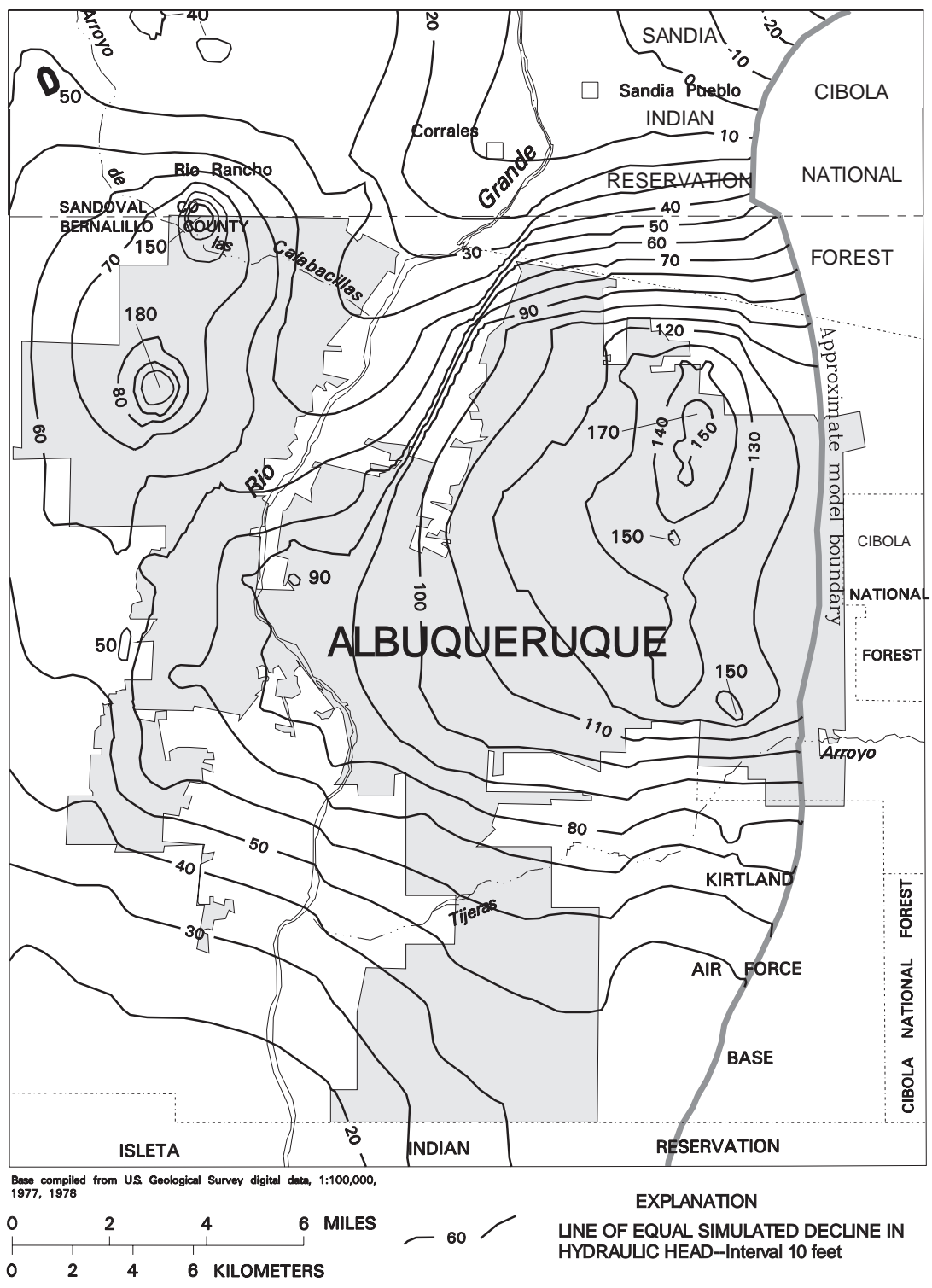

Figure 4. Simulated decline in hydraulic head in model layer 9 in the Albuquerque area assuming the current growth trend between 1995 and 2020. the Griegos well field in Albuquerque. This site is close to existing monitoring wells and to the Rio Grande and is isolated from other city production well fields. After 3 months of recorded ground-water recovery, the Griegos 1 well was switched on and pumped continuously for about 55 days with an average discharge of 2,330 gallons per minute. Twenty two monitoring wells were instrumented to provide a record of the changes in ground-water levels with time.

\section{Capitan Aquifer and Tansill Formation Data Collection}

The Capitan aquifer is the primary source of freshwater for the city of Carlsbad and several other communities in Eddy County and also a source of irrigation water for southeastern New Mexico. Water moves from Lake Avalon through channels in the Tansill Formation and mixes with water in the Capitan aquifer. This water then becomes part of the flow of Carlsbad Springs. Previous studies of the aquifer have indicated that water with dissolved-solids concentrations from 3,000 to 10,000 milligrams per liter (moderately saline) could be moving through the Tansill Formation and the Capitan Limestone from Lake Avalon to areas northwest of Carlsbad.

The USGS and the New Mexico State Engineer Office are compiling historical water-level, water-quality, and aquifer-test data for the Capitan aquifer in Eddy and Lea Counties and the Tansill Formation between Lake Avalon and Carlsbad and collecting new data in selected areas. These data will help support a better understanding and sound management of the water resources of the Capitan aquifer.

\section{Water-Quality Study of the Vermejo Irrigation Project}

The Maxwell National Wildlife Refuge in Colfax County is located near the center of the Vermejo Irrigation Project. The USGS, the U.S. Fish and Wildlife Service (USFWS), and the U.S. Bureau of Reclamation are cooperating in a study to determine if irrigation water from the project has significant potential to cause harmful effects to fish and wildlife or to impair other uses of the water in the wildlife refuge. Elevated concentrations of selenium in water, sediment, plants, and animals in the 
wildlife refuge have been detected in previous USFWS studies. These elevated concentrations may adversely affect the wildlife on the refuge, especially the migratory and resident birds that breed there. Several potential sources of selenium and other contaminants in the watershed upstream from the irrigation project include soils and bedrock, agriculture, coal mining and processing, and atmospheric deposition.

\section{Digital Map Coverage}

Digital elevation model (DEM) maps can be used to create three-dimensional perspectives of the landscape to assess slope and aspect for use in vegetation and habitat mapping. The USGS, in cooperation with the Bureau of Land Management and the U.S. Forest Service, has completed 1:100,000-scale DEM coverage for New Mexico. The status of 1:24,000-scale DEM mapping is shown in figure 5. DEM data consist of an array of regularly spaced elevations keyed to a USGS quadrangle map. The DEM's are merged at the University of New Mexico with satellite and aerial scanner data.

The USGS, in cooperation with the Natural Resources Conservation Service (NRCS), also is producing digital orthophotoquads (DOQ's). A DOQ is a digital image of an aerial photograph with displacements removed that are caused by the camera and the terrain. A DOQ combines the image characteristics of a photograph with the geometric qualities of a map. Present DOQ

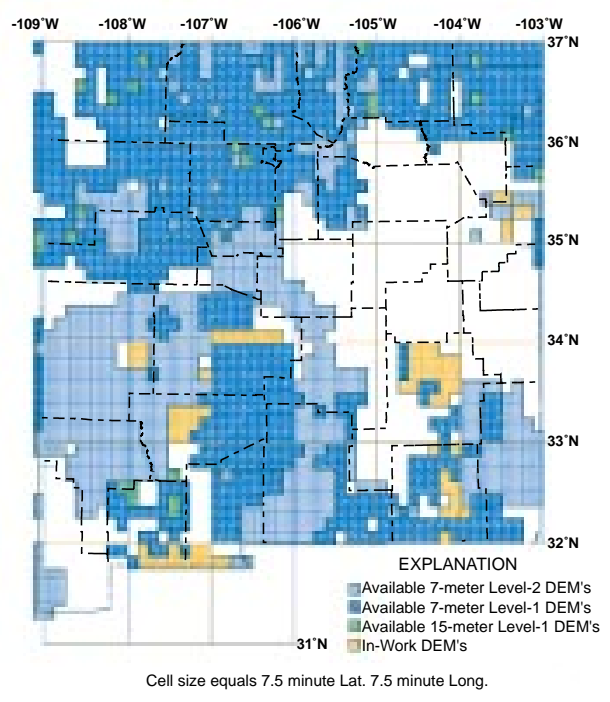

Figure 5. Status of 1:24,000-scale digital elevation model mapping in New Mexico.

coverage in New Mexico includes Cimarron and the Taos and the Zuni Indian Reservations. The NRCS applies DOQ's to soil surveys, conservation planning, and farm and ranch management. State agencies use DOQ's for toxic waste site and facilities management. Information about USGS DOQ's can be found on the World Wide Web at:

http://nsdi.usgs.gov/nsdi/products/doq.html

\section{National Water-Quality Assessment Program}

To provide nationally consistent information on water quality, the USGS implemented the National Water-Quality Assessment (NAWQA) Program. The goals of the NAWQA Program are to describe the status of and trends in the quality of a large representative part of the Nation's surfaceand ground-water resources and to identify the natural and human factors that affect their quality. This is useful information for policymakers and water managers at the Federal, State, and local levels. The

NAWQA Program is carried out through a series of study units that encompass important drainage basins and population centers. Two NAWQA Program studies are underway in New Mexico-in the Rio Grande Valley and the Southern High Plains.

During the highly intensive phase of the Rio Grande Valley study (1993-95), shallow ground water in the Albuquerque area and the San Luis and the Rincon Valleys was sampled and analyzed for major ions, nutrients, pesticides, volatile organic compounds, trace elements, and radon. Surface water was sampled at a fixed network for major ions, nutrients, and suspended sediments. Surface-water studies were conducted in the Mesilla Valley for pesticides and nutrients and in the upper Rio Grande Valley for trace elements. Ecological data on habitat assessment, fish population, algae, and invertebrate populations have been collected throughout the study area.

The Southern High Plains study focuses on the water quality of the High Plains (Ogallala) aquifer in parts of eastern New Mexico and the Texas Panhandle. The study also characterizes the water quality and ecological diversity of the thousands of playa lakes that provide nesting and winter habitat for millions of migrating waterfowl each year.
USGS State representative 4501 Indian School Road NE, Suite 200

Albuquerque, NM 87110-3929 (505) 262-5301

Fax: (505) 262-5398 Email: dc_nm@usgs.gov

Additional earth science information can be found by accessing the USGS Home Page on the World Wide Web at http://www.usgs.gov/

For more information on all USGS reports and products (including maps, images, and computerized data), call 1-800-USA-MAPS

The USGS provides maps, reports, and information to help others meet their needs to manage, develop, and protect America's water, energy, mineral, biological, and land resources. We help find the natural resources needed to build tomorrow and supply the scientific understanding needed to help minimize or miti-

gate the effects of natural hazards and environmental damage caused by natural and human activities. The results of our efforts touch the daily life of almost every American. Fact Sheet FS-031-96 